\title{
Assessment on Ultimate Load of Cold-formed Steel Channel (CFSC) Stub Column
}

\author{
Mohd Syahrul Hisyam Mohd Sani ${ }^{1,2, a}$, Fadhluhartini Muftah ${ }^{1,2, b}$, \\ Mohd Fakri Muda ${ }^{1, c}$ and Cher Siang Tan ${ }^{2, d}$ \\ ${ }^{1}$ Faculty of Civil Engineering, Universiti Teknologi Mara Pahang, Pahang, Malaysia \\ ${ }_{2}^{2}$ Faculty of Civil Engineering, Universiti Teknologi Malaysia, Johor, Malaysia
}

\begin{abstract}
Cold-formed steel is used as the non-structural and structural material in civil engineering work and building. Cold-formed steel channel is selected and cut into $100 \mathrm{~mm}, 200 \mathrm{~mm}, 300 \mathrm{~mm}, 400 \mathrm{~mm}$ and $500 \mathrm{~mm}$. The slenderness ratio is calculated and noted as a stub or short column because below 40 . The column is tested by using Universal Testing Machine to determine the ultimate load of the stub column. Besides, the CFSC is determined the material properties of CFSC for checking it's the originality of steel based material. The experimental data are tested and compared with the Direct Strength Method (DSM). It showed that the CFSC1 with a height of $100 \mathrm{~mm}$ is reported to have a higher value of ultimate load when compared with other samples. When the height of the stub column increased, the ultimate load of the sample is decreased. Then, the CFSC1 also showed a higher in initial stiffness when compared with other samples. All samples are shown having a higher data in ultimate load when compared with the Direct Strength Method prediction. The ultimate load of experimental and DSM all gave a ratio below 1.03. Finally, all samples can further recommend determining the relation between the ultimate loads with variations of height of the column.
\end{abstract}

\section{Introduction}

Cold-formed steel (CFS) is a steel based material that utilised in construction work as non structural or structural material. CFS with thin surface, lightweight and corrosion resistance is becoming a popular material in civil engineering and building. Normally, application of CFS in construction is as roof truss section, purlins, wall panel and frame due to the advantages of CFS. Nowadays, many researchers have studied the CFS as the main structure in buildings such as column, beam and retaining wall. CFS became more popular when compared with other traditional material. CFS is formed by processing of steel with galvanised coating in rolling, pressing and bending method at ambient temperature. CFS is produced in varieties of shape such as channel, $Z$, hat and compound sections. Additionally, CFS is formed into varieties of thickness, grade and cross-section. The design procedure of CFS is followed the Eurocode 3 and AISI.

The column is an important structure which required a safety and stability of the overall building. There are three types of structural column that be used in building. There is stub column or short column, intermediate column and slender column. In the study, the stub columns are selected to investigate the compression member in the roof truss member. Many researchers are studied the relationship of height and dimension in stub column such as Reference [1-4]. Reference [5] has studied the ultimate load capacity of CFS stub columns with non-perforated and perforated equal angle and compared with the Finite Element Model. Reference [6] has investigated the CFS column with inclined simple edge stiffeners and pin-ended support condition. The height of stub column, $500 \mathrm{~mm}$ is failed due to local and distortional buckling. Reference [7] has determined the strength behaviour of cold-formed steel non-symmetric lipped angle column and compared with design strength by using North American Specification. It showed that the design strength was quite conservative. The data of the ultimate load of the CFSC stub column are important in the design to be a reference guide that suitable for Malaysian condition and material.

This paper describes the experimental activity of compression on the CFS stub column to determine the relationship of different height. This data would be used as a reference in roof truss system, especially the roof truss member that noted as compression member. The main objective of this paper is to present an experimental program on the CFSC stub column.

\section{Experimental work}

Corresponding author: ${ }^{\mathrm{a}}$ msyahru1210@pahang.uitm.edu.my; ${ }^{\mathrm{b}}$ fadhluhartini@gmail.com; ${ }^{\mathrm{c}}$ fakri@pahang.uitm.edu.my; ${ }^{\mathrm{d}}$ tcsiang@utm.my 
Cold-formed steel channel (CFSC) section with the stiffener was used in the experiment. Normally, CFSC section is utilised in the roof truss system, especially as truss member, purlin, strut and bracing. Two steps in the preparation of the CFSC section for experiment were established. First Step, CFSC section is clean, clear and lastly, cut according to coupon tensile specimen that located at flat surface. The coupon tensile specimen is followed by a code of BS EN 10002-1, 2001 and used for checking the CFSC material properties. The coupon tensile specimens were extracted in the same direction of the column height that formed vertically and tested by using Universal Testing Machine (UTM) with a capacity of $100 \mathrm{kN}$. The extension control rate of $0.5 \mathrm{~mm} / \mathrm{min}$ and the extensometer of $50 \mathrm{~mm}$ gauge length to determine the strain of the coupon tensile specimen were used. Second step, the CFSC section was cut into 100, 200, 300, 400 and $500 \mathrm{~mm}$ height to form a stub column. The section dimension and properties of the CFSC section is shown in Table 1. The dimensional ratio of CFSC section was calculated as 34.00 for $b / t, 75.00$ for $d / t$ and 2.21 for $d / b$. The description, sample labels and the slenderness ratio of the CFSC section is shown in Table 2. All samples with the slenderness ratio below 40 were classified as stub column. The end support of the CFSC stub column was stated as a semi rigid support condition as shown in Fig. 1. The experimental result is compared with Direct Strength Method (DSM) by using software THINWALL.

Table 1. Section dimension and properties of Cold-formed steel channel section.

\begin{tabular}{|l|l|l|}
\hline Properties & Symbols & Value \\
\hline Section Dimension & Web, $d$ & $75.00 \mathrm{~mm}$ \\
\cline { 3 - 4 } & Flange, $b$ & $34.00 \mathrm{~mm}$ \\
\cline { 2 - 3 } & Lipped, $l$ & $8.00 \mathrm{~mm}$ \\
\cline { 2 - 3 } & Thickness, $t$ & \\
& & $1.00 \mathrm{~mm}$ \\
\hline Area & $A$ & $148.00 \mathrm{~mm}^{2}$ \\
\hline Direct Strength & $\gamma s$ & $550.00 \mathrm{MPa}$ \\
\hline \multirow{3}{*}{ Dimensional Ratio } & $b / t$ & 34.00 \\
\cline { 2 - 3 } & $d / t$ & 75.00 \\
\cline { 2 - 3 } & $d / b$ & 2.21 \\
\hline
\end{tabular}

Table 2. The description, sample labels and slenderness ratio of the Cold-formed steel channel column section.

\begin{tabular}{|c|c|c|c|}
\hline No & Test sample labels & $\begin{array}{l}\text { Column } \\
(\mathrm{mm})\end{array} \quad$ height & $\begin{array}{l}\text { Slenderness } \\
\text { Ratio }\end{array}$ \\
\hline 1 & CFSC1 & 100 & 7.73 \\
\hline 2 & $\mathrm{CFSC} 2$ & 200 & 15.46 \\
\hline 3 & CFSC3 & 300 & 23.18 \\
\hline 4 & $\mathrm{CFSC} 4$ & 400 & 30.91 \\
\hline 5 & CFSC5 & 500 & 38.64 \\
\hline
\end{tabular}

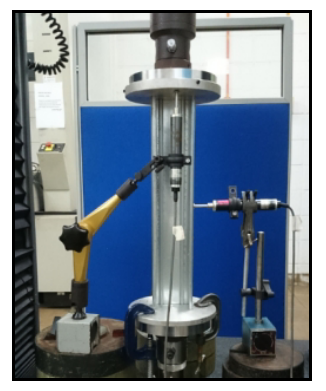

Figure 1. The configuration of CFSC stub column.

\subsection{Material properties}

The CFSC flat coupon tensile specimen was tested and the result was shown in Table 3 . The percentage difference between the web and flange for ultimate load and yield stress were recorded approximately $2.82 \%$ and $3.05 \%$ respectively. The ductility of the steel material is determined by using the ratio of $f u / f y$ and compared to the limit of $f u / f y$. The ratio of $f u / f y$ of the web and flange was stated same and more than 1.10 and classified as a good ductility.

\section{Result and discussion}

Table 3. The material properties of CFSC coupon tensile specimen and comparison with others testing.

\begin{tabular}{|c|c|c|c|c|c|c|c|c|}
\hline Sample & $\begin{array}{l}\text { Ultimate } \\
\text { Load (N) }\end{array}$ & $\begin{array}{l}\text { Ultimate } \\
\text { stress, } f u \\
\text { (MPa) }\end{array}$ & $\begin{array}{l}\text { Elasic } \\
\text { Modulus, E } \\
(\mathrm{GPa})\end{array}$ & $\begin{array}{l}\text { Extension at } \\
\text { Ultimate Load } \\
(\mathrm{mm})\end{array}$ & $\begin{array}{l}\text { Yield } \\
\text { Stress, fy } \\
(\mathrm{MPa})\end{array}$ & $\begin{array}{l}\text { Yield } \\
\text { Stress } \\
\text { factory, fyf } \\
(\mathrm{MPa})\end{array}$ & $f u / f y$ & fu/fyf \\
\hline
\end{tabular}




\begin{tabular}{|l|l|l|l|l|l|l|l|l|}
\hline Web & 6906.53 & 603.67 & 204.00 & 4.53 & 550.03 & 550.00 & 1.097 & 1.097 \\
\hline Flange & 7106.87 & 628.48 & 206.00 & 5.27 & 567.38 & 550.00 & 1.108 & 1.143 \\
\hline
\end{tabular}

The compression of CFSC stub columns was tested and the results were tabulated in Table 4 . The table was tabulated the ultimate load of experimental, load of Direct Strength Method (DSM) and the ratio of $P_{D S M} / P_{U L T}$. The ultimate load of the CFSC stub columns was decreased when the height of the column increased. From the table, percentage different of ultimate load and stress between CFSC1 with CFSC5 was reported $35.15 \%$. Comparison percentage of the CFSC1-CFSC2, CFSC2CFSC3, CFSC3-CFSC4 and CFSC4-CFSC5 was recorded $6.00-15.00 \%$. The compressive extension at ultimate load of CFSC stub columns was increased by increasing the height of the column exclude CFSC1. The difference between CFSC1 and CFSC2 was stated about $5.48 \%$. The CFSC1 was shown lower than CFSC2 because the section was very short and difficult to get the accurate result. As a result, all CFSC stub columns were reported having a local buckling as shown in Fig. 2 and Fig. 3. From the observation, the flange and web at the middle height was moved inside or outside of the origin shape and line.

The highest initial stiffness is CFSC1 with 73199.65 $\mathrm{N} / \mathrm{mm}$ and second highest among the CFSC stub column is CFSC3 with $44675.32 \mathrm{~N} / \mathrm{mm}$. Initial stiffness of CFSC2, CFSC4 and CFSC5 was noted approximately $42020.17 \mathrm{~N} / \mathrm{mm}, 27664.33 \mathrm{~N} / \mathrm{mm}$ and $29434.39 \mathrm{~N} / \mathrm{mm}$, respectively. The percentage difference between the CFSC1 (highest value) and CFSC4 (lowest value) was determined about $62.21 \%$. All samples were recorded between $0.60-1.03$ of $P_{D S M} / P_{U L T}$ when compared between ultimate load and load from DSM. From the calculation and observation, the relationship of the height of stub column and load of experimental and DSM was established as shown in Fig. 4.

Table 4. The result of the compression testing of CFSC column.

\begin{tabular}{|c|c|c|c|c|c|c|}
\hline Sample & $\begin{array}{c}\text { Ultimate } \\
\text { Load, } P_{\text {Ult }}(\mathrm{N})\end{array}$ & $\begin{array}{l}\quad \text { Ultimate } \\
\text { Stress } \\
\left(\mathrm{N} / \mathrm{mm}^{2}\right)\end{array}$ & \begin{tabular}{lr}
\multicolumn{2}{c|}{ Compressive } \\
Extension & at \\
Ultimate & Load \\
$(\mathrm{mm})$ & \\
\end{tabular} & $\begin{array}{l}P_{D S M} \\
(\mathrm{~N})\end{array}$ & $\begin{array}{l}\text { Failu } \\
\text { re Shape }\end{array}$ & ${ }^{P_{u l t}} P_{D S M}$ \\
\hline CFSC1 & 68240.37 & 461.08 & 1.587 & $00^{45540 .}$ & $\mathrm{L}$ & 0.67 \\
\hline CFSC2 & 60982.13 & 412.04 & 1.500 & ${ }_{00} 38890$. & $\mathrm{L}$ & 0.64 \\
\hline CFSC3 & 51793.61 & 349.96 & 1.748 & $00^{37430 .}$ & $\mathrm{L}$ & 0.72 \\
\hline CFSC4 & 47268.61 & 319.38 & 2.608 & ${ }_{00} 41340$. & $\mathrm{L}$ & 0.87 \\
\hline CFSC5 & 44253.45 & 299.01 & 2.980 & $00^{45370 .}$ & $\mathrm{L}$ & 1.03 \\
\hline
\end{tabular}

Note: L - local buckling

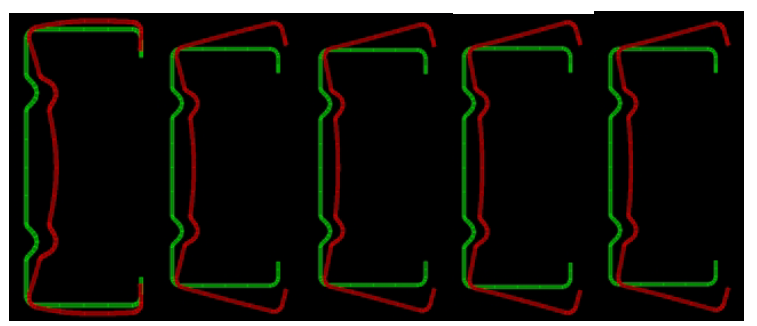

Figure 2. The failure shape of CFSC1, CFSC2, CFSC3, CFSC4 and CFSC 5 by using software THINWALL.

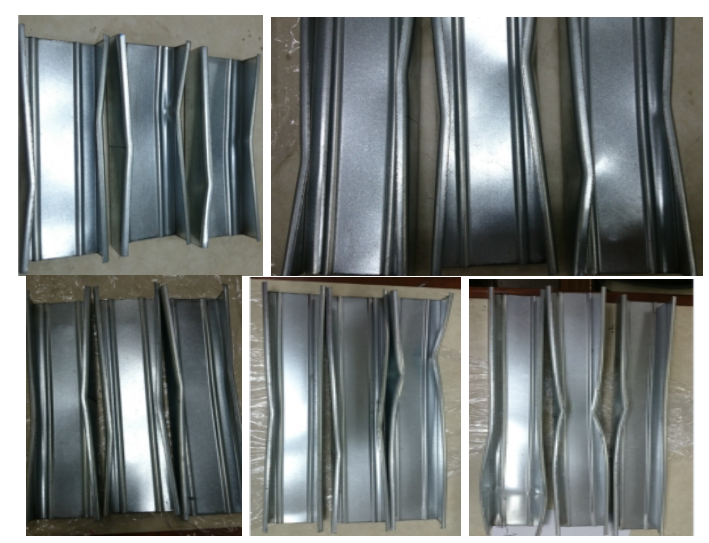

Figure 3. The failure shape of CFSC1, CFSC2, CFSC3, CFSC4 and CFSC 5 by experimental. 


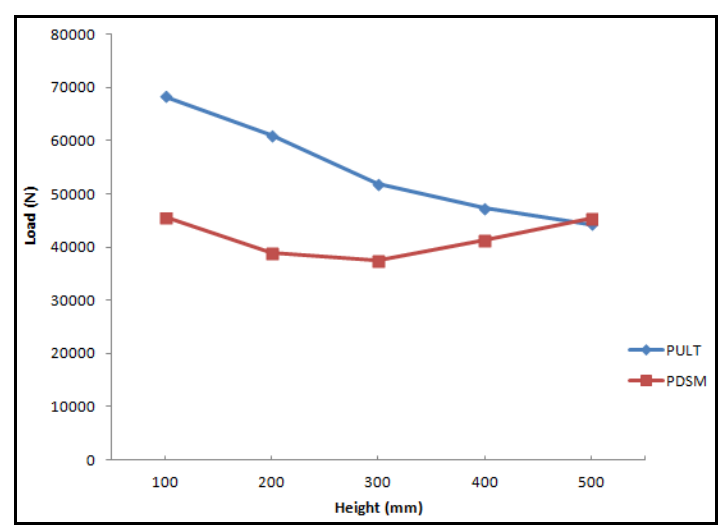

Figure 4. The relationship between the heights of the column with load of experimental and DSM.

\section{Conclusions}

A study of the CFSC stub column with different height of the column has been carried out and analysed in the paper. The verification of the experimental and standard also has been done to provide the reasonable data result. From the results, the following concluding statement can be drawn out:

1) From the experiment, the ultimate load and stress are calculated by depends on the height of the column. With an increment of the height of the column, the ultimate load of the experiment is reported decrease about $6-15 \%$. All samples of the column are reported to have the local buckling due to the slenderness ratio below 40 that classified as stub column.

2) The initial stiffness of CFSC1 and CFSC5 are noted $73199.65 \mathrm{~N} / \mathrm{mm}$ and $29434.39 \mathrm{~N} / \mathrm{mm}$, respectively. Normally, the initial stiffness is depended on the height of the column.

3) All samples are noted approximately 0.60 to 1.03 of $P_{D S M} / P_{U L T}$ when compared between the load of experimental and standard.
Further work should be done for varies of column length that classified as a stub, intermediate and slender column to produce the relationship in slenderness ratio and give a reference guide in design of compression member of cold-formed steel.

\section{Acknowledgements}

The authors gratefully acknowledge the financial support from the Universiti Teknologi Mara (UiTM) Pahang and Universiti Teknologi Malaysia (UTM) Johor. Thanks also extend to Faculty of Civil Engineering and Faculty of Mechanical Engineering of UiTM and UTM for providing machinery and equipment. Special thanks are extended to the lecturer and technician of UiTM Pahang and UTM Johor Bharu for their help during the experimental program.

\section{References}

1. Q.Q. Liang, S. Fragomeni, Journal of Constructional Steel Research 66, 159-169 (2010)

2. B. Uy, Z. Tao, L.H. Han, Journal of Constructional Steel Research 67, 360-378 (2011)

3. Z. Tao, B. Uy, F.Y. Liao, L.H. Han, Journal of Constructional Steel Research 67, 1719-1732 (2011)

4. V.B. Nguyen, C.J. Wang, D.J. Mynors, M.A. English, M.A. Castelluci, Journal of Constructional Steel Research 69, 20-29 (2012)

5. M. Dhanalakshmi, N.E. Shanmugam, $15^{\text {th }}$ International Specialty Conference on Cold-formed Steel Structures, St. Louis, Missouri, USA, Oct. 1920, 2000.

6. Y. Zhang, C. Wang, Z. Zhang, Journal of Constructional Steel Research 63, 383-395 (2007)

7. B. Young, J. Chen, Journal of Constructional Steel Research 64, 808-815 (2008) 